\title{
The Fragility of Dissent!: Mediated Resistance at the Gleneagles G8 Summit and the Impact of the 7/7 London Bombings
}

ABSTRACT: Informed by ethnographic methods, this article takes a case study approach to the protests of the Dissent! network at the 2005 Gleneagles G8 Summit. Of interest is how activists anticipated, understood and reflexively navigated the 'mediated opportunity' and shifting media dynamics of the G8 Summit. The analysis focuses largely on the representational reverberations of the July $7^{\text {th }}, 2005$ London bombings ( $7 / 7$ bombings) on Dissent! protests. It is argued that the bombings reinforced the fragility and temporality of mediated resistance, and also emphasised the lack of control social movement actors have over mediated spaces of resistance.

Keywords: Social movement, protest, antiglobalisation, mediation, London bombings, media.

RESUMEN: adoptando un método etnográfico, este artículo presenta un estudio de caso sobre las protestas realizadas por la red Dissent! durante la cumbre del G8 en Gleneagles en 2005. Es reseñable la manera en que los activistas anticipan, comprenden y negocian de forma reflexiva la oportunidad mediatizada y la dinámica cambiante de los medios de comunicación en relación con la citada cumbre. El análisis realizado se centra en las consecuencias representacionales para las protestas de Dissent!, derivadas de los ataques terroristas del 7 de julio en Londres. Los ataques terroristas refuerzan la fragilidad y temporalidad de la resistencia mediatizada al tiempo que se enfatiza la falta de control que los agentes de los movimientos sociales tienen sobre los espacios mediatizados de resistencia.

Palabras clave: movimiento social, protesta, antiglobalización, mediación, ataques terroristas de Londres, medios de comunicación. 


\section{Introduction}

On July $6^{\text {th }}, 2005$, the $31^{\text {st }}$ G8 Leader's Summit opened at the luxury hotel complex of Gleneagles in Perthshire, Scotland. In tandem with the delegates meeting, dissenters gathered, behind lines of soldiers, riot police, fences and mounted police which protected the 850 -acre lot of the five-star hotel. Some who had gathered, such as Make Poverty History and Live 8, sought to influence G8 leaders through lobbying by spectacle; undertaking massive media campaigns and holding rock concerts (Gorringe and Rosie, 2006; Nash, 2008). Others, such as the Dissent! Network of Resistance (Dissent!), the focus of this article, also drew upon a repertoire of spectacle to engage in 'performed violence' (Juris, 2008) - predominantly through road blockades - as a means to continue the symbolic disruption of, and challenge to, the hegemonic representational legitimacy of the G8 Summit.

G8 Summits - along with the meetings of other international organisations - have evolved from the sequestered gatherings of the economic elite to fullscale political media events whereby discursive, symbolic and physical struggle unfolds on the «public screen» (DeLuca and Peeples, 2002: 134). G8 Summits offer significant 'political opportunities' (Tarrow, 1998) to both reinforce dominant political structures and to challenge them. Focussing on the latter opportunity, this article argues for the need to conceptualise 'media events' such as the Gleneagles Summit as reflexive sites for struggle and resistance that are on par and in tandem with more traditional, material, spaces of contention.

While radical resistance in the media arena has become integral to the practice of activism, this article argues that the mediated space around such events is fragile, temporal and beyond the control of activists. To illustrate this point, the bulk of the analysis herein focuses on the representational reverberations of the July $7^{\text {th }}, 2005$ London bombings ( $7 / 7$ bombings) on the Gleneagles protests. The bombings, it is argued, provide empirical evidence as to the fragility and temporality of mediated resistance. To this end, the analysis highlights the lack of control social movement actors have over the mediated spaces of resistance opened up around the G8 Summit. Further, it examines social movement actors' reflexive awareness of this precarious position as captured in their reflections on the abrupt closure of the mediated space around G8 Summit protests soon after news of the $7 / 7$ bombings reached the camp. Attention is also given to the ways in which activists imagine and negotiate potential further protests at the G8 in Scotland in light of the immediate resurgence of discourses of 'terrorism' in the aftermath of the London bombings. 


\section{Dissent!, Hori-Zone and the 2005 Gleneagles G8 Summit}

Three significant networks emerged to contest the 2005 G8 Gleneagles Summit. Make Poverty History was the largest of the three networks which, at its peak, consisted of a network of over 500 British and Irish NGOs, religious groups and high-profile celebrities. Second, G8 Alternatives was a smaller, largely Scottish network of trade unions, political parties, NGOS and academics. Its key event was a marshalled march past the fence of the Gleneagles Hotel on July $6^{\text {th }}, 2005$, the first day of the G8 Summit, attended by over 10,000 people. The Dissent! - Network of Resistance Against the G8 (Dissent!), was an «anticapitalist» network driven by autonomous politics with roots in the British environmental direct action movement. The smallest of the three networks, Dissent! envisioned itself as a non-hierarchical network comprised of organisations, autonomous collectives and individuals. Dissent!'s structure carried forward the model of autonomous, purpose-oriented networks which have mobilised around international meetings since the late 1990s (Cammaerts, 2007; Juris, 2008).

For the protests in Scotland, Dissent! established the Hori-Zone eco-village and 'convergence space' in Perthshire, Scotland, which provided space for 5,000 campers. Hori-Zone was a space to both plan and conduct resistance with around 1,000 activists departing from the camp to take part in blockade-type actions on Dissent!'s July 6 $6^{\text {th }}$, «Day of Action». Also based at Hori-Zone was the CounterSpin Collective (CSC), an autonomous collective comprised of Dissent! network members who formed a working group to facilitate media interaction between activists and mainstream media at the camp. For CSC members, and indeed some other Dissent! activists, the symbolic narrative of the G8 was a site of struggle interwoven with more traditional, material, spaces of contention such as city streets. To consider this point further, theoretical work is first needed to establish the media, and particularly the G8 Summit as a media event, as temporal mediated space for structuring, resisting and challenging contemporary power relations.

\section{Politics and Counter-Politics in an Age of Mediation}

Issues of power are central to processes of globalisation and are at the root of politics and counter-politics. Power, drawing on Castells, in its most basic form can be conceived of as «the structural capacity of a social actor to impose its will over other social actor(s)» (Castells, 2007: 239). Power, in the information society, is no longer concentrated in institutions but distributed over networks. This has, according to Castells (1997: 360), established electronic 
media as «[...] the privileged space of politics.» Recently Castells reasserted this argument suggesting that «the media are not the holders of power, but they constitute by and large the space where power is decided» (Castells, 2007: 242). Thus, for Castells electronic media create a «space» - what Gamson and Wolfsfeld (1993) called the «media arena» - for struggles over power through the definition, control and challenging of symbolic narratives, to play out.

While I support Castells' view of media creating a space for the contestation of power, his argument that media are «not the holders of power» overlooks the power of media to open and close the media space as well as set the rules of entry. Consequently, this article argues that the «space» created by media, invoking Giddens' (1984: 374) «duality of structure», is both «the medium and outcome» of media processes. Thus media hold power in their infrastructural role in maintaining the media arena and their role within it; their ability to shape rules of access to the space - through, for example, news values and journalistic conventions and practices - as well as the ability to construct and represent reality to publics through the production and distribution of media content. The media also simultaneously - collectively, yet in different degrees and contexts create an environment for social actors to engage in their own struggles over and for power particularly, as is the focus of this article, in politics and counterpolitics within the logics of media structures and the process of mediation.

Viewing the media arena as more than just a space but, a temporal, fragile and reflexive environment, requires viewing media - its construction, circulation and consumption - as a broad, messy and overlapping process of mediation. Rooted in a growing literature on mediation (Couldry, 2008; Livingstone, 2009; Silverstone, 1999, 2007), mediation is defined as an uneven and often contested process that involves multiple social actors - individuals, collectives, institutions, networks - in the (re)construction, (re)circulation and (re)consumption of symbolic forms. It further recognises that the process of mediation occurs on multiple, overlapping levels across a range of experiences on an ongoing, reflexive basis within the political, social and technological context of a society. Mediation opens a door, an orientation to analysing how social relations and power struggles characterise life in contemporary society.

While mediation is presented as a process, Couldry (2004) has convincingly outlined how it may be operationalized through studying «media-oriented practices». Practices are defined as «a routinised type of behaviour which consists of several elements, interconnected to one another: forms of bodily activities, forms of mental activities, 'things' and their use, a background knowledge in the form of understanding, know-how, states of emotion and motivational knowledge» (Reckwitz, 2002: 249). Focusing on media-oriented practices provides a means to break from media-output centred analysis to study the «ordering» of social practices both towards and by the media (Couldry, 
2004). In this article, an emphasis on practice provides a means to consider how - through the analysis of interview transcripts coupled with participant observation - social movement actors within Dissent!, and particularly those from the Counter Spin Collective, made sense of the media environment and how this understanding reflexively informed their political strategies as social movement actors in the planning and execution of political contention within the media arena.

\section{Methodology}

This article is based on empirical data gathered from a larger research project (McCurdy, 2009), which explored the 'media-oriented practices' (Couldry, 2004) of anti-capitalist activists within a specific network - Dissent! in their preparation and enactment of protest at a specific media event: the 2005 Gleneagles G8 Summit. The study was premised on Burawoy's 'extended case method' which is a qualitative approach to social research characterised by a 'sensitivity to process', an appreciation for context and a goal of building on social theory (Burawoy, 1998). The theoretical concern which drove the larger research project was a desire to explore the utility of a 'mediation approach' as a means to move beyond the previous compartmentalised study of media/movement scholarship and view the media as an environment that activists live with, in and through. In taking a 'mediation approach' the study was empirically interested in the media knowledge and practices of social movement actors as a means to examine how activists anticipated, understood and navigated their mediated environment.

To capture empirical data, the extended-method supports a case-driven ethnographic research strategy that employs multiple 'research techniques' to ensure robust data collection. The extended-method is characterised by its endorsement of the researcher taking an active, participatory role in the research to enrich understanding. Consequently, this project involved a year of overt «theory-driven participant observation» (Litcherman, 2002) with Dissent! prior to and at the 2005 G8 Summit. Fieldwork began in December 2003 consisting largely of electronic participant observation on relevant network listservs until October 2004. From October 2004 until August 2005, I regularly attended local and national Dissent! meetings and continued to participate actively on multiple Dissent! network listservs. The most intense period of fieldwork was the on-theground G8 mobilisation from June 29, 2005 to July 9, 2005 in Scotland.'

1. A detailed overview of participation within Dissent! along with a critical reflection on this process is provided in McCurdy (2009). 
Throughout the fieldwork my focus was on attending meetings and being at sites where mainstream media were anticipated to be discussed or present. ${ }^{2}$ During fieldwork notes were taken, movement documents (paper and electronic) archived and mainstream media articles logged. This data was largely used to compare with and consider themes from activist interviews as means to explore activists' 'media oriented practices'.

In tandem with participant observation, 30 semi-structured interviews were conducted with 24 participants all of whom were members of Dissent! (6 participants were interviewed twice - before and after the G8 Summit accounting for 12 of the 30 interviews). Interviews were conducted at various stages during the mobilisation between March 2005 and August 2005. Wherever possible, interviews were conducted face-to-face though 4 interviews were conducted by telephone and 1 by email. On average, interviews lasted 45 minutes. Interviews were semi-structured and followed an interview schedule ${ }^{3}$ with questions designed to explore activists' views around the significance of mediated protest and the Gleneagles Summit as a media event. Meanwhile, activists involved in the CounterSpin Collective within Dissent! were asked about the specific media strategies (media practices) designed and deployed at the protest. For interviews conducted on and after July 7, 2005, a question was added to capture activists' reflections on the London bombings and its impact on the protests.

Full transcripts were produced for all 30 interviews totalling 444 singlespaced pages of text. Transcripts were analysed via 'thematic coding' (Flick, 1998) using Atlas.ti to manage coding. The coding process was aided by asking interviewees parallel questions and then coding responses across interviews. A coding framework was generated based on pre-defined theoretical areas of interest focussing on how activists made sense of and navigated the media environment around the G8 Summit. ${ }^{4}$ The framework was created by analysing one transcript and then continually assessing and modifying the framework in relation to subsequent transcripts.

Codes were grouped on an 'activist level' as means to capture perceptions and understandings of media. For example, one of the largest individual grouping of codes dealt with what was coded as «news filters», which were the various processes perceived by individuals to influence news content. Thematic codes were also used to capture 'group level' discourse and reflections on the

2. For more detail see McCurdy (2009).

3. For interviewee profiles and to view the interview schedules used see McCurdy (2009).

4. A full list of codes and more detailed consideration of the coding process is presented in McCurdy (2009). 
CounterSpin Collective with the largest group of codes falling under the banner of 'repertoire' which was used as a catch-all to capture media-oriented practices suggested by interviewees. 'Network level' codes were used to capture discussions about Dissent!, its actions and media policy.

In analysing interview transcripts, field notes and movement documents, efforts were made to think consistently about the thematic interrelations and identify common themes and codes across the data in order to increase the 'internal validity' of the research. Nonetheless, this is an 'exploratory study' interested in how a sample of contextually-situated social movement actors perceived and involved themselves with processes of news production in planning and enacting contentious politics at sites connected to the Gleneagles G8 Summit. Consistent with the objective of the 'extended method' to develop and 'extend' social theory, the broader objective herein was to develop and 'extend' theory to view the media as an arena which is a site for struggle and resistance that is fragile, temporal, yet has become an integral component of radical resistance.

\section{Dissent!, Mediated Resistance and the Gleneagles G8 Summit}

Drawing on themes from the qualitative analysis of empirical data gathered around the Gleneagles G8 Summit, this section considers how activists' understanding of the shifting media dynamics surrounding the G8 Summit informed their practice of activism. ${ }^{5}$ It opens by unpacking a view widely expressed by Dissent! activists within and outside of the CounterSpin Collective (CSC) that the media must be seen as a field of social struggle on par and in tandem with other sites. Next, the temporality of the mediated opportunity provided by the G8 Summit is illustrated through a selective ethnographic account and key interview extracts pertaining to the impact of the London 7/7 bombings. The final empirical section captures activists' reflexive awareness and sensitivity to the changed media dynamics brought about by the bombings to the practice of their activism.

\section{Media as a Battleground - Perspectives on Mediated Resistance}

Activists from Dissent!, many of whom were members of the CounterSpin Collective (CSC), interviewed for this research viewed the media as a site of

5. For full research results see McCurdy (2009). 
struggle on par and in tandem with more traditional, material, spaces of contention such as city streets. This perspective is captured well by Darren: ${ }^{6}$

For me, mainstream media is just like any other social field, a field of struggle. The Summit protest actually is one of the crucial fields of struggle. We don't just want to leave it to that, so to speak, because the police talk to the media, you know. Bob Geldof talks to the media, excessively. So, if we don't, we lose a lot of the potential that is here in these global media spaces. (Interview with Darren, 07/08/2005, my emphasis).

The argument made by Darren, which was echoed by many other activists interviewed, reflects academic assertions, most notably Castells (1997: 360) who viewed media as a crucial contemporary space for struggle. While this is an established and accepted academic perspective, its expression by 'unprofessionals' and particularly activists affiliated with a radical network that is premised on abstaining from mainstream media interaction, is significant. It indicates the beginnings of a shift in thinking by, at least some, radical social movement actors whereby mainstream media is no longer seen only as an adversary to be avoided, but a battlefield where adversaries - including the media - must be engaged with.

Also evident in Darren's articulation of «global media spaces» is a view of media power similar to Castells (2007: 242) in that the media are not holders of power but create an arena to battle with political opponents. Darren's view concerning the necessity of engaging with media was shared by all interviewees affiliated with the CSC - an activist collective who took responsibility for devising strategies to interact and manage mainstream media - and many other non-CSC interviewees. Common amongst activists with this perspective was a belief that a policy of not interacting with mainstream media - such as the network-level media policy of Dissent! - did not prevent media coverage but simply allowed others, particularly the authorities and political opponents, to dominate the media space and ultimately (mis)represent Dissent!. This perspective is captured in the reflections of Gregory, «I just think it's kind of crazy not to engage with the mainstream media because they're going to say what they like about you and you should just at least try and have some kind of impact on it» (interview with Gregory, 26/07/2005). Here, Gregory uses «they're» to capture the field of competing social actors (news sources) in the media arena posturing to dominate and frame symbolic narratives. These remarks, which resonate with Darren's remarks above, capture a perspective prevalent amongst interviewees that media is an arena where social struggle

6. All names used in this article are pseudonyms. 
takes place and therefore should be engaged with as part of the practice of activism.

Within Dissent!, the view that media should be actively engaged with was not universal and was a source of debate and tension. The specifics surrounding 'the media debate' are discussed elsewhere (McCurdy, 2010). Despite this debate, important at present is that a large body of activists viewed media as a crucial arena for contention. Significantly, for the majority of activists interviewed, the role of media was doubly articulated as a site or arena for and something to struggle against. This was often evident in activists' articulations, such as in the above excerpt from Gregory, whereby interviewees expressed concerns as to the limitations of mediated struggle due to the ability for media to set the rules of access to the media arena and shape the representation of G8 resistance (McCurdy, 2011, forthcoming). This view of media power, which was prominent amongst activists interviewed, sees media power as doubly articulated residing simultaneously in the capacity to maintain a mediated space for contention but also holding power in their ability to represent contention.

Although Dissent! activists generally viewed the media as a field of struggle, they specifically saw the Gleneagles G8 Summit as a «political opportunity» (Tarrow, 1998: 118) to enter the arena. Tarrow (1998) defines political opportunity as consisting of a window for contention (an opportunity) as well as the recognition and seizure of the opportunity. Surprisingly absent from Tarrow's scholarship - and severely underdeveloped within social movement research - is the identification of media discourse as a source of opportunity. Nonetheless, the G8 Summit was clearly identified by Dissent! activists as a mediated opportunity for struggle. In the words of one interviewee, the G8 was «too big of an opportunity not to [protest]» (interview with Scott, 22/09/2005). From Mary's perspective the Gleneagles G8 Summit offered a «window of opportunity to get a message out to a much wider public» (interview with Mary, 08/07/2005). Implicit in Mary's comment is a recognition of the G8 Summit as a news event; an opportunity with a capped media lifespan. A significant difference between activists involved with the CSC and Dissent! members more generally was the view of mainstream media as an opportunity, a site of struggle and therefore something worth struggling over, that differentiates the perspective of those in the CSC from the network-level orientation of Dissent!. Thus while the majority of Dissent! activists staying at the Hori-Zone camp set out on blockading actions in the early hours of July $6^{\text {th }}$, 2005 - actions indirectly oriented to the media - members of the CounterSpin Collective stayed behind to deal directly with the representational blowback of those actions which manifested in a flock of journalists descending upon HoriZone eager to elicit a media comment on the protests. 


\section{7. «We had our 15 minutes» - The July $7^{\text {th }}$ London Bombings}

Soon after blockaders set out from Hori-Zone on July $6^{\text {th }}$, security repercussions were felt at the protest camp. From about 8 am that morning police used their powers to declare a Section 60 under the Criminal Justice and Public Order Act 1994, giving the police the powers of stop and search. The Section 60 remained in effect throughout the $6^{\text {th }}$ and onto July $7^{\text {th }}$. Around 2:30am on July $7^{\text {th }}$, the police strengthened their presence at Hori-Zone by deploying approximately 26 vans of riot police to assist in sealing the camp's entrance by means of the controversial «kettling technique»; nobody was allowed in or out «for the safety of the public».

Hori-Zone's heightened security captured the attention of international media and, from 7 am on July $7^{\text {th }}$, journalists began hovering around the site but were not allowed to go inside the «kettle». Around 9:20am rumours of a «power surge» on the London Underground circled the camp. Soon after, it became clear that the «power surge» was, in fact, a coordinated series of bombings.

At Hori-Zone it was difficult to obtain information about the unfolding events in London. On site there was one small television inside a trailer beside the gated entrance that some individuals gravitated towards. However, capacity was capped to about 40 people standing three deep, with others flowing outside of the trailer simply to listen to the news. People also began assembling around automobiles in the camp parking lot that had car stereos tuned to BBC Radio 4.

By 10am, a little over an hour after the bomb blasts, the scale of the events in London was clear to all: police, activists, and media alike. The London bombings had two clear impacts on Hori-Zone. First, it marked the end of media interest in Dissent! as the performative G8 protests were upstaged by a more spectacular, consequential and visceral act of violence which took the lives of 52 innocent commuters and injured 700 others. The media space opened for protest around the G8 Summit was immediately closed to protestors. Second, the interpretation of activists (along with journalists and politicians) of the $7 / 7$ bombings within «terrorist» discourse and the larger «War on Terror» caused Dissent! activists in Scotland to reflect upon and restrain their own actions to prevent any association with the London bombings. Both of these points will now be considered in detail.

\section{The Media Frame Closes, Hori-Zone Remains Open}

The London bombings of July $7^{\text {th }}$ brought an abrupt, tragic and unexpected end to media coverage of the protests against the Gleneagles G8 Summit. This 
closure of the media space was visible in the activity and presence of journalists at Hori-Zone. By 11am the majority of international journalists who were present at the camp had left with those remaining being almost exclusively local journalists. Claudia described the scene at Hori-Zone following the news of the bombings as follows:

There was a lot of media hanging around outside the camp in the days following 07/07. They were literally lying on the grass, having a kind of break, and feeling lucky that they weren't in London, probably. They weren't interested at all, because they knew that there was no-one actually asking them for a story. So that was the direction they were getting [...] The focus had just gone, basically, and you could see it, visibly. At one minute they were kind of like vying at the gates for interviews and trying to get in, and the next minute they were all just lying around having a picnic. So, we'd say 'we're not really the story any more, are we?' 'No, we've got to be here just in case anything happens' but they knew that. [...] that was it, really. (Interview with Claudia, 25/08/2005)

It was not just journalists who recognised the closure of the media space. Activists also recognised this. Robyn commented the following:

I think that in terms of the media, as soon as London happened, it was over. The G8 protests from that moment on were over. There was going to be no interest whatsoever. Maybe from local media because it is in their backyard. But anybody else, forget it. It was over. We could have just gone home then as far as the media was concerned. (Interview with Robyn, 21/07/2005)

Above, Robyn exhibits an awareness of the news production process which is applied to make sense of her own position as an activist in Scotland against the backdrop of the London bombings. Below, Hamish offers a similarly reflexive analysis which exhibits an application of his understanding of news cycles and newsworthiness against his own position as someone demonstrating against the G8:

In the grand scheme of things, I don't think, and also the nature of news reporting and stuff, it's the hot issue of the day as well. And I don't mean to sort of belittle in any way what went on in London, because it was fucking bad and disgusting and totally deserved to get as much coverage as possible. And that's where people's interest is going to lie. So yeah, I wasn't surprised that media sort of didn't have as much interest or time or resources to put to what it is that we were doing. We were the story of the day for awhile. We had our 15 minutes. (Interview with Hamish, 09/07/2005) 
The comments of Claudia, Robyn and Hamish capture the importance of emphasizing the temporality of mediated spaces. While such spaces are inherently temporal given the fluid nature and limited attention span of twentyfour hour news media, such spaces for resistance are also vulnerable to external happenings which cause space opened by a mediated opportunity to abruptly close.

Returning to interview material, Guy felt that the sudden way in which the protests were ended by the London bombings illustrated instability and temporality of the contemporary media environment:

It was sort of an indication really that you can do your groundwork for a million years and talk to friendly journalists all you like but, when another bigger story with more bleeding comes on the scene they will drop you. Because you are only there because you are sort of shiny and you are the thing of the month. And it shows how suddenly we can just you know, spend years and years preparing [and] can just sort of disappear off the media. (Interview with Guy, 15/08/2005)

Neither Guy, nor any of the other interviewees, expressed comments which questioned the significance of the London bombings; its importance - and therefore newsworthiness - was taken as a given by all. What is interesting about Guy's comment is his recognition of the utility of Dissent! to the media as temporal, dramatic copy but only to the extent until something more spectacular happens. From this perspective, the power of media is not just in its ability to create a space for resistance as Castells (2007) argues, but in its power to take that space away or for that space to be taken away by another happening.

Guy's comments, along with those of Claudia, Robyn and Hamish also highlight activists' reflexive awareness of how Dissent!'s precarious and temporal status in the representational arena is underwritten by and thus subject to «media logic» (Altheide and Snow, 1979) and external events beyond their control. Further, activists' articulations of how news media work through their references to news values and news cycles and the like, also demonstrate how a perceived understanding of news media can influence the practice of activism.

\section{Activist Reflexivity and Representation - Reflections on 7/7}

The 7/7 London bombings not only meant the closure of the media space but also caused many Dissent! activists to rethink their protest strategies. In the wake of the bombings, activists were mindful of the possibility that any future contentious acts could be misrepresented by media and misunderstood by the public: 
When the bombings actually happened, it meant - I guess it changed the whole atmosphere of the camp. Like, our actions - we didn't want to be disrespectful to what happened or to be given the opportunity to be taken completely out of context, you know? Like «violent protestors celebrate as London burns». Whatever trashy headline they want. (Interview with Chris, 20/07/2005)

Some interviewees also expressed concern that additional protest from Hori-Zone immediately after the bombings would be picked up by politicians to delegitimize the idea of protesting against the G8 and simultaneously legitimise an increase in security measures at Hori-Zone:

I remember getting the phone calls on the Thursday morning and immediately ringing friends at Stirling to beg them not to demonstrate as they had the day before - some sort of presence yes, but they would be hammered by the media and politicians if they engaged in any civil disobedience and they would also be physically hammered by the cops - . It didn't matter in the end because the police completely surrounded the camp. I know that most people felt the same - we can't protest while people have just been bombed because it looks bad and how we are portrayed is very important - we were already being hammered but to go out the next day as if we didn't care would have been a disaster. (Interview with Harry, 28/08/2005, my emphasis)

Interviewees Chris and Harry are conscious of the representational complications of engaging in contentious politics immediately after the London bombings. Harry's emphasis on the importance of the representation of resistance reaffirms earlier arguments around activists viewing the media as an arena to engage in struggle. The material protests in Scotland are also envisioned as being undertaken at the level of media image ad discourse (RETORT, 2005).

The reflexive comments of both activists - Harry's plea to fellow activists not to protest «as they had the day before» and Chris' articulation of a «changed atmosphere» - also captures how the normative strategies of spectacular resistance such as direct action and police confrontation which, while acceptable in the media event frame of G8 protest, in the context of a terrorist attack were no longer seen as appropriate. Activists' understanding of the reconfigured media environment post $7 / 7$ and the potential representational limitations and risks of action in this environment shaped and severely limited the further enactment of contentious politics. Activists' perceived need to reconsider their protest actions in the light of the reconfigured media space of the London bombings captures how the changing nature of the structure of the media space is feedback into the practice of activism. Theoretically, this response provides further support for the need to understand the space created by media not simply as a concrete arena «media and outcome» (Giddens, 1984) of the process of mediation. 
Despite the need felt by many activists to keep their actions in check, the reality was that there was little protest planned for July $7^{\text {th }}$. Moreover, the policing of the camp was such that any actions that would have been planned for July $7^{\text {th }}$ or beyond would, more than likely, have been severely hindered by the police. One action that did go ahead on July $7^{\text {th }}$ was the rather spontaneous creation of a memorial in solidarity with, and in memory of victims of the London bombings. The following quote from Sarah reflects both the mood of the camp and the memorial:

I think it was huge, because the atmosphere went from being fairly defiant and celebratory to a kind of... I mean, the way I remember it, it's the kind of sort of silence descended on the camp and some sort of weird perspective came into peoples heads...the weird thing was the whole camp calmed down. Like, the police calmed down. You know, the campers calmed down. Like, there was a general feeling of calm because nobody quite knew where to go with it. What had happened. It was really strange. Then there was that vigil where [...] police and protesters all lit candles at the camp... and all of a sudden there was this weird unification of the fact that something wider had happened that no one had expected. And people were shocked by it. (Interview with Sarah, 21/07/2007)

The London bombings evoked an emotional response from many activists, a state of disbelief and silence. Moreover, it saw a paradoxical and certainly fleeting merger between activists and authorities, two groups who had previously been engaged in both a physical and symbolic struggle, both lighting candles at the memorial in an act of remembrance and tribute to the victims of the London bombings. The symbolic contest that had previously played out on the ground and in the media had ended. The media frame had shut and the media event was eclipsed. Dissent!'s fifteen minutes were over.

By the afternoon of July $7^{\text {th }}$ attention had turned away from protest and towards returning home. July $8^{\text {th }}$ and $9^{\text {th }}$ saw a steady stream of activists leaving Hori-Zone. Over these two days police maintained their presence at the camp and continued their searches, but movement to and from the camp was much more open in a bid to encourage activists to leave. Moreover, on July $8^{\text {th }}$ police organised a free train from Stirling to London in a further effort to reduce activist numbers. By the time I left the camp, on the afternoon of July $9^{\text {th }}$, the last official day of Hori-Zone, it was all but deserted, and only the camp take-down crew remained. Although the G8 Summit had only officially concluded a day prior, activists and particularly the media had moved well beyond the protests of the Gleneagles G8 Summit. 


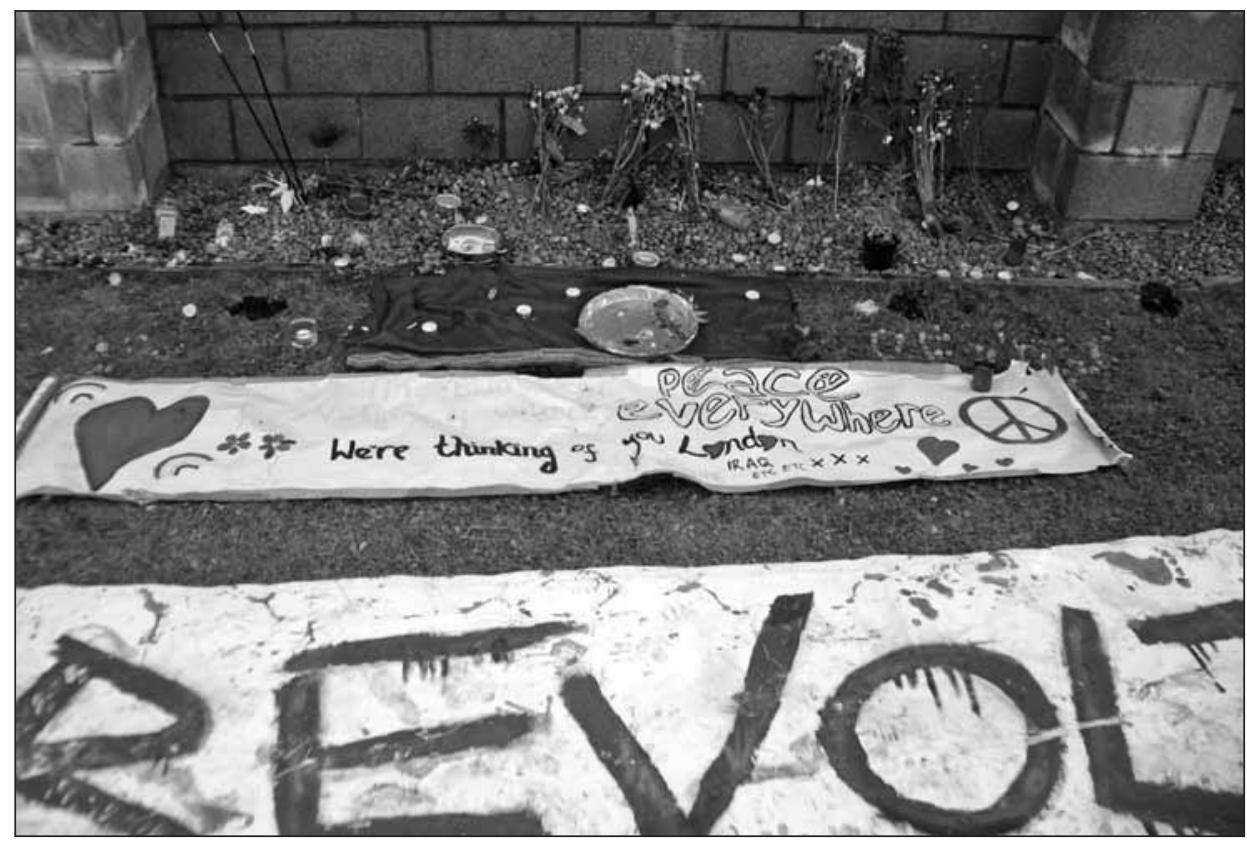

Fig. 1. Photograph of the 7/7 memorial created by activists at the Hori-Zone camp, Stirling, Scotland

\section{Resistance in an Age of Mediation}

In taking a «mediation approach» the study was empirically interested in the media knowledge and practices of social movement actors as a means to examine how activists anticipated, understood and navigated their mediated environment. The analysis of fieldwork notes and of interview transcripts captures activists' reflexive awareness of the mediated environment and sensitivity towards this environment. This awareness was particularly evident in the articulations around the changed media dynamics brought about by the bombings. Activists realised that not only had the media dynamics changed, but also reflected on how these events influence their positions as activists and the undertaking of further protests based on the potential of negative representation.

The theoretical concern which drove the larger research project was a desire to explore the utility of a 'mediation approach' as a means to move beyond the previous compartmentalised study of media/movement scholarship and view the media as an environment that activists reflexively live with, in and through. In line with this perspective, this article has presented the media arena as not only a site of struggle and resistance that activists are aware of and see as an integral 
component of radical resistance, but a site that is fragile, temporal and largely beyond the control of social movement actors. Highlighting both the temporality of spaces of mediated contention and activists' awareness of this necessitates revisiting Castells' arguments around media power.

This article began by arguing that contemporary political contention increasingly takes place with and through the media (Castells, 2000, 2007; Couldry, 2004; Silverstone, 1999, 2007). The arguments presented herein offer further support to such academic claims as captured in Dissent! activists' view of the media as a site for social struggle. However, it would be a mistake simply to view the media as providing a platform for power struggles. To this end, I quoted Castells who recently argued, «the media are not the holders of power, but they constitute by and large the space where power is decided» (Castells, 2007: 242). In the same article Castells (2007: 239) defined power as «the structural capacity of a social actor to impose its will over other social actors». For Castells the media are institutions that do not possess power but are structuring agents - architects - who largely build arenas for struggles over power. While Castells recognises that media have the ability to create «rules» for accessing the media space, such as in establishing news values, but does not equate this to a form of power.

This view of media, it has been argued, is incorrect. Moreover, it militates against previous research which acknowledges the asymmetrical relationship between media and social movements (Gamson and Wolfsfeld, 1993). The media must not only be seen as creating an environment for struggle over power but also as holders of power. The media hold symbolic power in their infrastructural role in maintaining a space for politics, shaping rules of access and representing reality. Moreover, power exists not only in the ability to create a space for struggle, but to take away or close the media space. It could be retorted that the closure of the media space around the G8 Summit due to the London bombings was not necessarily an exercise of power by the media but instead a result of - and therefore an illumination of - the limits of the architecture of the media system. Even so, there remains the need to go beyond Castells' architectural view of mediated space and afford due consideration to the infrastructural role, and the implications thereof, as both «the medium and outcome» (Giddens, 1984) of the process of mediation.

An architectural view of media also poses a danger of losing sight of the temporality, instability and fragility of mediated resistance and media spaces. While such spaces in an age of 24-hour news are inherently temporal, the impact of the London bombings on the protest at Gleneagles captures the temporality and vulnerability of representational space. Thus, if the media is understood as a battleground for the control over the production of symbolic narratives and power relations, its volatility must be recognised. 
Indeed, in the wake of the London bombings activists within Dissent! were aware of changes in the representational space recognising the immediate closure of symbolic protest space at the G8 Summit as well as the re-emergence of discourses of «terror». Moreover, many Dissent! activists also called for a reconsideration of protest strategies to adapt to the reconfigured media space. The desire expressed by Dissent! activists to change their actions in light of potential media representation highlights an additional avenue for considering the infrastructural power of media through analysing the ways in which social actors have accepted, internalised and (re)oriented their actions on the basis of their understanding of the logic of media (Altheide and Snow, 1979). Consequently, future academic inquiry is needed into how political actors make sense of their media environment and how this understanding informs and underwrites their practice of politics.

In conclusion, the protest planned and enacted by Dissent! at the 2005 Gleneagles G8 Summit has presented a case study of contemporary political resistance in an age of media saturation where resistance is simultaneously physical and symbolic. It has further highlighted the temporality of symbolic spaces as demonstrated by the impact of the $7 / 7$ bombings. Finally it has called for further academic research into how politics actors' understandings of symbolic terrains inform their practice of politics and counter politics. It is hoped the arguments presented herein can act as a catalyst towards such research.

\section{Works Cited}

Altheide, D.; R. Snow (1979): Media Logic, London, Sage.

Burawoy, M. (1998): «The extended case method», Sociological Theory, 16(1): 4-33.

Cammaerts, B. (2007): «Media and communication strategies of glocalized activists: beyond media-centric thinking» in Cammaerts, B.; N. CARPENTIER (eds.) (2007): Reclaiming the Media: communication rights and expanding democratic media roles, Intellect, Bristol. 265-288.

Castells, M. (1997): The power of identity, vol. 2, Oxford, Blackwell.

- (2007): «Communication, power and counter-power in the network Society», International Journal of Communication, 1: 238-266.

Couldry, N. (2004): «Theorising media as practice», Social Semiotics, 14(2): 115-132.

- (2008): «Mediatization or mediation? Alternative understandings of the emergent space of digital storytelling», New Media and Society, 10(3): 373392. 
DeLuca, K. M; J. Peeples (2002): «From public sphere to public screen: Democracy, activism, and the "violence" of Seattle», Critical Studies in Media Communication, 19(2): 125-151.

FuICK, U. (1998): An Introduction to Qualitative Research, London, Sage.

Gamson, W.; G. WolfSFeld (1993): «Movements and media as interacting systems», The Annals of the American Academy of Political and Social Science, 528: 114-125.

Giddens, A. (1984): The Constitution of Society, Berkeley, University of California Press.

Gorringe, H.; M. Rosie (2006): “"Pants to poverty”? Making poverty history, Edinburgh 2005», Sociological Research Online, 11(1): n. p.

JURIS, J. S. (2008): Networking Futures: The Movements Against Corporate Globalization, London, Duke University Press.

Kellner, D. (2003): Media Spectacle, London, Routledge.

Litcherman, P. (2002): «Seeing structure happen: Theory-driven participant observation» in Klandermans, B.; S. Staggenborg (eds.) (2002): Methods of Social Movement Research, London, University of Minnesota Press. 118-145.

Livingstone, S. (2009): «On the mediation of everything: ICA presidential address 2008», Journal of Communication, 59(1): 1-18.

MCCURDY, P. (2010): «"I predict a riot" - Mediation and political contention: Dissent!'s media practices at the 2005 Gleneagles G8 Summit», unpublished $\mathrm{PhD}$ dissertation, London School of Economics and Political Science.

- (2011, forthcoming): «Breaking the spiral of silence - Unpacking the «media debate» within Global Justice Movements: A Case Study of Dissent! and the 2005 Gleneagles G8 Summit», Interface, 2(2): 42-67.

NASH, K. (2008): «Global citizenship as show business: the cultural politics of Make Poverty History», Media, Culture \& Society, 30(2): 167-181.

RECKWITz, A. (2002): «Toward a theory of social practices: A development in culturalist theorizing», European Journal of Social Theory, 5(2): 243-263.

RETORT (2005): Afflicted Powers: Capital and spectacle in a new age of war, London, Verso.

Silverstone, R. (1999): Why Study the Media?, London, Sage.

- (2007): Media and Morality: On the rise of the mediapolis, Cambridge, Polity.

Tarrow, S. (1998): Power and Movement: Social Movements and Contentious Politics, $2^{\text {nd }}$ ed., Cambridge, Cambridge University Press. 